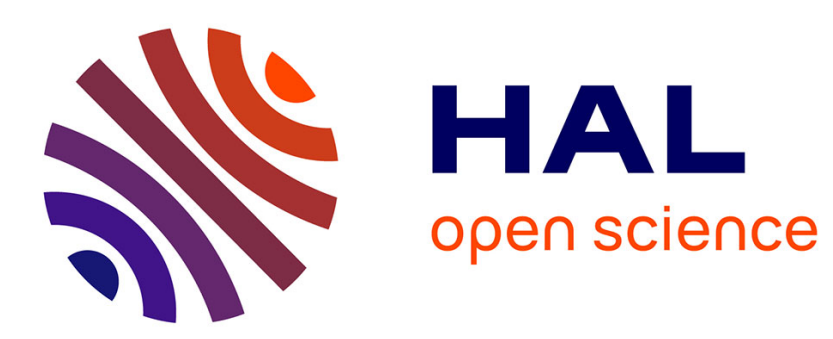

\title{
Bourdieu and Psychoanalysis: An Empirical and Textual Study of a Pas de Deux
}

\author{
Muriel Darmon
}

\section{To cite this version:}

Muriel Darmon. Bourdieu and Psychoanalysis: An Empirical and Textual Study of a Pas de Deux. Sociological Review, 2016, 64 (1), pp.110-128. 10.1111/1467-954X.12349 halshs-02305342

\section{HAL Id: halshs-02305342 \\ https://shs.hal.science/halshs-02305342}

Submitted on 1 Feb 2020

HAL is a multi-disciplinary open access archive for the deposit and dissemination of scientific research documents, whether they are published or not. The documents may come from teaching and research institutions in France or abroad, or from public or private research centers.
L'archive ouverte pluridisciplinaire HAL, est destinée au dépôt et à la diffusion de documents scientifiques de niveau recherche, publiés ou non, émanant des établissements d'enseignement et de recherche français ou étrangers, des laboratoires publics ou privés. 


\title{
Muriel DARMON
}

\section{Bourdieu and psychoanalysis: an empirical and textual study of a pas-de-deux}

\author{
Abstract
}

This paper aims to elucidate some of the similarities between the Bourdieusian and a psychoanalytical approach to understand the individual and the social, and to describe Bourdieu's relation to psychoanalysis. The paper begins by reflecting upon the way a research on anorexia was received and perceived by some psychiatrists and psychoanalysts. Such a case study puts into light several analogies between Bourdieu's theoretical position, his epistemological style and psychoanalysis. Then, some texts by Bourdieu, especially a discussion with the psychoanalyst and sociologist Jacques Maître, are analyzed in order to further explore Bourdieu's position vis-à-vis psychoanalysis and to assess the influence of psychoanalysis on his conception of the individual habitus. Finally, the paper discusses the possible contradictions arising between these borrowings and the principles of Bourdieusian epistemology. The paper thus suggests that the Bourdieusian approach is better analyzed as a 'sociologisation' of psychoanalysis rather than as an approach complementing or integrating psychoanalysis. 
Total word count : 8829 


\section{Introduction}

It is not an easy task to find explicit references to psychoanalysis in Bourdieu's texts. As noted by commentators who broached this topic (Fourny, 2000 ; Steinmetz 2006) Bourdieu's texts have the specificity of being increasingly peppered with psychoanalytical terms - 'unconscious, misrecognition, projection, reality principle, libido, ego splitting, negation, repression, phallonarcissism, compromise formation, and anamnesis' (Steinmetz, 2013 : 108) - but without much explicit confrontation or discussion with psychoanalysis as a disciplin. Apart from more lenghty passages in his later books, such as The Weight of the World and Pascalian Meditations, only a few quick notations or implied references can be spotted here or there. Even looking for answers in settings where Bourdieu was clearly asked about his psychoanalytic engagements does not provide the researcher with substantial material to elaborate about the connections of his work with the psy-field. When Bourdieu participated in 1992 in the renowned workshop organized by long-time followers Gérard Mauger and Louis Pinto 'Lire les sciences sociales', he was asked by Mauger a question about the habitus and the potential resemblance between 'socio-analysis' and psychoanalysis : 'Do you analyze the way socio-analysis can work on the social unconscious the same way Freud analyzes the effects of psychoanalysis on the unconscious?' (Mauger and Pinto, 1994 : 314). Bourdieu answered without refering to psychoanalysis, but with a quick snap at the psychologisation of social problems, using in inverted 
commas... a psychoanalytic term ('displacement'): '[Socio-analysis] can provide people who suffer with some ways of understanding a little better what is happening to them, instead of "displacing" their problems, for example in the psychological direction' (Mauger and Pinto, 1994 : 318).

Significantly, the one text that among French sociologists interested in these matters is usually thought to convey Bourdieu's position towards psychoanalysis, has not been written by Bourdieu himself and is found hidden in a book by the recently deceased Jacques Maître, both a sociologist from Bourdieu's school and a psychoanalyst, which exact reference reads: Jacques Maître, avec Pierre Bourdieu, 'Avant-Propos dialogué', in Jacques Maître, L'Autobiographie d'un paranö̈aque, Paris, Economica, 1994, p. V-XXII

Such a - most likely voluntary - ambiguity of position by Bourdieu, calls for clarification. This paper aims to elucidate some of the similarities between the Bourdieusian and a psychoanalytical approach and to describe Bourdieu's position. Commentators have already discussed Bourdieu's relation to psychoanalysis, but from a theoretical perspective (Steinmetz, 2006, 2013 ; Fourny, 2000 ; Muel-Dreyfus, 2003). Instead of proceeding in a purely theoretical manner, the paper will begin by an experiment of sort aimed at grasping relations 'in practice' between Bourdieusian and psychoanalytical orientations: I will reflect upon the way my research on anorexia (Author, 2009), inspired in part by Bourdieu, was received by psychiatrists and 
psychoanalysts. Such a case study will display (and not merely discuss) the affinities between Bourdieu's sociology and psychoanalysis. Then, I will draw from the discussion Bourdieu had with the psychoanalyst and sociologist Jacques Maître to describe Bourdieu's position, and assess the influence of psychoanalysis on his conception of the individual habitus. Finally, the paper will discuss the possible contradictions arising between these borrowings and the principles of Bourdieusian epistemology, especially its definition of a sociological right to scientific imperialism and its repeated claims about the 'social' nature of the conscious and the subconscious at the individual level. The paper suggests that the Bourdieusian approach is better analyzed as a 'sociologisation' of psychoanalysis rather than as an approach subordinated to, complementing or integrating psychoanalysis.

\section{Presenting a Bourdieusian research to}

\section{psychoanalysts: experiencing 'hooked atoms'}

Before I offer a clarification of the terms of engagement of Bourdieusian thinking about psychoanalysis through a reading of Bourdieu's texts, I introduce my argument empirically by focusing on the ways in which a sociological study I conducted was received and perceived by a group of psychoanalysts to whom I presented it. Such a tiny and, except for me, unimportant experience is indeed a way to put into light the 'hooked atoms of 
the field'i between Bourdieu's theoretical position, his epistemological style and psychoanalysis.

The study I wish to present briefly here (since it is not the primary focus of the article, but an illustration of the arguments that follows) is a qualitative research on anorexia. The idea was to propose a consistently sociological way of looking at what is most commonly seen as a 'psychological' and 'pathological' state. As a sociologist, I wanted to study anorexia empirically, through fieldwork. I did not want to limit my scope to the various contexts of anorexia (historical or social), but rather to try and show what a sociological eye could bring to the study of anorexia itself, or anorexia 'in practice'.

In her groundbreaking book on the social history of anorexia, Joan Jacobs Brumberg distinguishes between the questions that can be raised and answered by social scientists (such as the history of the diagnosis, the sociocultural context of the pathology, the analysis of its specific recruitment) and those which could not, namely 'the subsequent "career" as an anorexic [which is] obviously the concern of medicine and mental health professionals' (1988: 3840). My study fails to comply with such division of labour between disciplines. It focuses on anorexic day-to-day practices and representations, on what happens during anorexia, on what anorexics actually do, and not on what they represent or symbolize. 
Such an approach of 'anorexia in practice' is all the more necessary, given that the vast majority of social sciences or gender studies of anorexia is concerned with the various discourses on anorexia (be that the medical, the popular, or the anorexics' discourses) or with what anorexia 'symbolizes' or 'means' (Bordo, 1993; Turner, 1996), and thus take little interest in the anorexic activity itself, with sometimes no other data than secondhand material. Another way of putting it would be to say that, instead of jumping to posit an anorexic subjectivity or an anorexic ontology, even a socially constructed one, I first want to study sociologically 'what anorexia is' through what anorexics do. This is why I use the notion of (deviant) 'career' to 'turn people into activity' (Becker, 1998), and to shift from a definition of 'identity' to one of action: one is not born an anorexic, one must become one, and to 'be' (labelled) anorexic, one has to 'do' certain things.

I do not, however, stop at the sequencing of the anorexic career, and I try to extend the analysis. To 'do' those things, you have to 'be' someone specific: what do the people who are doing those things 'have to be' to do what they're doing? In the traditional interactionist use of the notion of career, the social proprieties of the individual are neglected (or even refused) as explanatory, i.e. as reasons to enter a deviant career. As far as anorexia is concerned, this seems rather problematic, since the recruitment of the pathology is both specific and enduring: the vast majority of anorexic patients are adolescent girls from uppermiddle to upper classes (McClelland and Crisp, 2001), as happened also in my own study where I defined class membership based on both parents' and 
grandparents' occupations and diplomas (Author, 2009) (Bourdieu, 1979). In my perspective, these social properties are indeed taken into account, but in a second step, and as social conditions of possibilities of the anorexic career. The interviewees' habituses, which I study, is both what makes the anorexic career possible and what is modified along the various phases of the career, as a result of a specific work of self-transformation performed by the anorexics.

This is why my study of anorexia is structured in two different and successive moments, and combines an approach of the anorexic career with a study of the anorexic habitus (Author, 2009). What is important for my demonstration here, is the fact that the book this study gave birth to, published in 2003, is clearly divided into two parts, related to the 'career', as in the interactionist approach, and to the habitus in social space, as in the Bourdieusian approach.

The first part offers a reconstruction of the anorexic career, based on an interactionist approach of deviance, and describes the anorexic activity as a selfconversion work. The second part of my work (and of the book) on anorexia is the analysis of the anorexic habitus and its social space. The set of practices that constitutes the anorexic career are located in a specific place within the social space. For example, what the interviewees eat and what they don't eat is not chosen randomly, or only according to the calorie intake of each food. Food selections reveal 'dominant tastes' (Bourdieu, 1979) for they single out foods that are consumed in greater amounts by upper classes still today in France 
(fruits and vegetables, fish and seafood, yoghurts...). Anorexia is therefore not only about 'restricting' food: it is about choosing a certain type of food, with certain properties, both caloric and social. And this is done at the expense of other foods, which are strongly associated with working-class tastes, such as bread, charcuterie, or plats en sauces. Anorexia is therefore an extreme but relevant case in point to show the enduring social class distinctions of eating practices, tastes and distastes (Wills et al., 2011; Rhys-Taylor, 2013). More generally, anorexic food practices, body practices and school practices, however weird or pathological they may appear, echo those of the upper and middle classes from which comes the majority of anorexic patients. They therefore reveal the construction, at the result of the conversion work of the anorexic career, of an anorexic habitus which can be located within the social space of social classes.

This summary of my results aims at showing that the interactionist deviant career orientation and the Bourdieusian one are, to a large extent, separated in the book, and this is also how I am used to present my arguments: in two distinct 'moments'.

Another duality must be mentioned, regarding the settings of the research. It was conducted in France and based on repeated in-depth interviews with 14 anorexic patients from different hospitals and five months of observations of the everyday life and talk therapy sessions in the units they were hospitalized 
in, together with interviews with some of their teachers (11 interviews), snowball interviews of formerly diagnosed anorexics (three) and comparative interviews on body and food practices with high-school girls (11 interviews). The persons interviewed as anorexic patients were all adolescent girls, and were all from upper and middle classes (Author, 2009). More precisely, the research was conducted in two different hospitals, representative of two antagonistic 'approaches' to anorexic treatment (Luhrmann, 2000) within psychiatry. The first hospital was of a biomedical orientation : in spite of the differences or even conflicts between the members of the medical teams, they believed in a multifaceted explanation of anorexia where biological factors were prominent, had no difficulties in using profusely the official diagnostics and diagnoses manuals, and were used to prescribe drug therapy (combined with a behavioural and cognitive approach) at the core of the treatment. The second hospital was, conversely, of a psychodynamic and psychoanalytical orientation: the teams looked for causes of anorexia in the patients' past, family past and family dynamics, medics were reluctant to use official diagnostics classifications, interpreted the biological and practical manifestations of anorexia as mere symptoms, and used talk therapy as the main and most recognized course of treatment. Over the years, I presented my study in both institutions, as well as in a dozen of other medical settings, broadly belonging to one or the other of the two therapeutic orientations. It is from these presentations of two different kinds of sociology to two different kinds of psychology, that I draw the 'impressions' and the data - or 'quasi-data', since I 
cannot claim to have performed a real sociological study of reception-- that I use here.

To put it in a nutshell, each part of my research - which I labelled according to their main sociological allegiance as the 'anorexic deviant career' or the 'anorexic habitus' - resonated strongly with, respectively, the biological/biomedical, or the psychodynamic/psychoanalytic therapeutic orientations.

I shall focus in this paper on the case of the psychoanalysts' responses to the Bourdieusian analysis, linking the 'anorexic habitus' part of my research and the psychoanalytic orientation, because this is a productive means to engage the discussion I wish to develop about Bourdieu's relationship with psychoanalysis. Therefore I will only mention here that the biomedically oriented psychiatrists had many reasons to feel closer to the deviant-career part of my work, which they favoured and spontaneously understood, and to partake in its criticisms of functionalism but also psychoanalysis (Becker, 1964). On the other hand, psychoanalysts and psychoanalytically-minded psychiatrists clearly favoured the arguments, results and findings of the Bourdieusian part of my book - the anorexic habitus -, both because of what the approach was up against and because of what it stood for, as I will show now. 
Psychoanalysts approved my choice of drawing from a Bourdieusian approach in my study of anorexia, first because it meant critizising a 'descriptive' approach of the anorexic career and studying the individual predispositions that make the progression into such a career possible. The description of the anorexic career in the first part of my book was inspired by a Beckerian definition of a deviant career (Becker, 1963, 1998): the reasons or causes to enter the career are not to be taken into consideration, the question being 'how' people engage in a particular activity and not 'why' they do it. Whenever I presented results from my study and the reasons to go from Part I (the anorexic career) to Part II (the anorexic habitus), I argued that the career approach was missing the fact that 'not everybody' had the same probability to enter into an anorexic career or stay on its path, and that the anorexic activity actually presupposes some class predispositions that can account for the specifity of the upper-class recruitment of the pathology (Author, 2009).

This actually loosely resembled how psychoanalysts criticize behavioural psychology and biological approaches, as only focused on a 'symptom', and as lacking historical depth in the study of the individual. Psychoanalytical audiences also approved of the epistemological shift entailed by moving from Becker to Bourdieu, because they perceived it as switching from description to explanation, from the given to the hidden, from a pragmatically-viewed present (what people are doing) to a deterministic and enduring past (what people are, or have to be, to do what they do). As I argued that social conditions of 
possibilities were necessary to enter the anorexic career, and that statistics showed that two-thirds of the patients come from the upper classes, they heard that 'studying the symptom' without taking into account the psychic construction of the individual during childhood and adolescence leads to only a partial apprehension of the anorexia phenomena.

In a more positive manner, the psychoanalytic audiences often exhibited interest in the core Bourdieusian idea of the influence of primary socialization, of the persistent making of the individual within the first years of his or her existence. The Bourdieusian approach evidently shares with psychoanalysis a principle summarized in a sentence by Durkheim often quoted by Bourdieu (1980: 94) :

Within us lies in various proportions Yesterday's man. And it is even him who is predominant in us, since present is but a very small thing compared to this long past where we were formed and from which we result (...) Yesterday's man is the unconscious part of ourselves. (Durkheim, 1938: 18-19)

As Francine Muel-Dreyfus (2003: 228) puts it, Bourdieusan sociology, as psychoanalysis, 'gives a great deal of room for the uncouscious' and 'must fight against the amnesia of genesis which eternalizes and reifies concepts and categories, thus naturalizing the social'. This is why my quest for 'Yesterday's woman' within anorexic patients and my various invocations of the social past 
of patients as explaining their conduct - be that the individual past of the socio-genesis of a given habitus, or the collective past of history - always resonated strongly with the psychoanalytical audience. It was the case whenever I threw light upon today's anorexia with a reference to the construction of the modern 'universe of class bodies' (the social hierarchy of bodily shapes and styles) (Bourdieu, 1979) at the end of nineteenth century, when thinness and emaciation went from stigma of poverty to status symbols and attributes of the 'leisure classes' (Author, 2003). It was also the case whenever I took into account the individual past of the socio-genesis of a given habitus. The anorexic patients I interviewed displayed social dispositions that could be related to their middle- and upper-class upbringings. Manifestations and proofs of the weight of the social past of their class socialization on their present behaviour were always welcome by the psychoanalytic audiences, both as familiar and as complementary with their own point of view. This was for example what happened whenever I presented my analyses of the anorexic ethos of 'control' over corporeal destiny - the body can and will be transformed - and showed it was characteristic of middle and upper classes and in contrast with a more fatalist body acceptance in the working classes. Similarly, the interviews displayed a more general ethos of control over social destiny which appears also to be connected with a specific class socialization (Author, 2003, 2009). The fact that I did not resort to the usual psychological explanation of the 'urge for control' (supposedly typical of anorexics) did not prevent psychoanalysts to feel familiar and attuned to the idea of explaining 
such a behaviour within a family past, even if the strong point of my explanation related to a social class past.

To summarize what I want to draw from this account of the presentations of my research to psychoanalytic inclined audiences: my argument is that these manifest preferences both for what a Bourdieusian approach criticized (the epistemological choice of 'description' and the obliteration of the past) and provided (causal explanations of behaviours and attention to individual and group history) are not a coincidence, but proceed from the 'elective affinities' between the Bourdieusian and the psychoanalytical approach, and their respective positions within the fields of sociology and psy-fields or particular branches of medicine. Between the two main sociological orientations I presented - the interactionist deviant career and the anorexic habitus -, the psychoanalytic audience 'chose' the one that most resembled its own (Bourdieu was embraced as a sociologist they could 'think with') and the one that was opposed to a kind of sociology - the interactionist - that resembled a psychiatric position they were up against (Bourdieu was also embraced as a sociologist they could 'criticize with').

\section{A 'pas de deux' between sociology and psychoanalysis}


Once experienced and delineated, the proximity I found between Bourdieu and psychoanalysis can appear quite self-evident. This makes all the more surprising the very small number of explicit references to psychoanalysis made by Bourdieu in his books over the years, with the exception of some more explicit engagements in his later writings - The Weight of the World and Pascalian Meditations.

In The Weight of the World, published in French in 1993, the word 'Psychoanalysis' appears twice in the Index - which is rare, the word seldom appears in Bourdieu's other indexes. ${ }^{\text {ii }}$ Psychoanalysis is mainly discussed in the last two pages of 'The Contradictions of Inheritance', a text written by Bourdieu, where Freud is quoted once. But we note that this discussion begins with a very striking statement: 'This is not the place to question the relation between the mode of exploring subjectivity proposed here and that practiced by psychoanalysis' (Bourdieu, 1999: 512).

In Pascalian Meditations, published in French in 1997, 'psychoanalysis' does not figure in the Index rerum (Freud is referenced four times in the Index nominum, though), but 'psychological operations', described in explicit psychoanalytic terms (projection, identification, transference, sublimation, etc.) are discussed more extensively in the book and especially in the first pages of Chapter 5, called 'Libido and illusio' (Bourdieu, 1997: 197-201). 
I will return to the content of these texts, but let me just note now that, all in all, the explicit discussions of psychoanalysis by Bourdieu do not amount to much given the 'obvious' proximity referred to above and compared, for example, to the way Bourdieu deals with history, or with economics, in his books. Among French sociologists interested in the connections between sociology and psyfields, the advice given to academics looking for more has always been to read a text, not written by Bourdieu himself, but which is supposed to convey 'his' position on the subject of psychoanalysis. This text is the preliminary section (called an 'Avant-propos dialogué', 'Foreword in the form of a dialogue') of L'Autobiographie d'un paranoïaque by Jacques Maître, published in 1994.

Since this book is not translated into English, let me present in some details the content of its preamble. It is indeed cast as a dialogue between Bourdieu and Maître, of which I will discuss three important themes: the question of the dialectics between instincts and institutions, the difference between 'institution' and 'field', and the affinity with psychoanalysis as an acquired right for Bourdieu's sociology following years of what he calls 'repression'.

\section{The dialectics between instincts and institutions}

Bourdieu begins by praising Maître for having chosen to conduct a methodical and scientific enquiry on subjects usually tackled in essays, such as the 
relationship between sociology and psychoanalysis, and more specifically, the question of the cathexis (investissement) in institutions - Maître had mainly studied the religious institution and Christian mysticism. According to Bourdieu, the various cases studied by Maitre (such as Sainte Thérèse de Lisieux, or Madeleine Lebouc, a patient of the nineteenth century psychologist Pierre Janet) make it possible to see 'how dispositions (as potentialities) are actually related to certain institutions, or, better, certain fields (as array of possibilities); how social agents exploit institutions to satisfy their instincts (pulsions) (...), and how institutions, conversely, make the social agents' instincts serve their own ends' (Maître and Bourdieu, 1994: VI). ${ }^{\text {iii }}$ Later in the text, Bourdieu elaborates on the 'general dialectics' between the individual (ie, in this text, his or her dispositions, instincts, personal history) and the institution: 'the investment in the institution and the investment by the institution, coercion and adhesion, etc.' (Maître and Bourdieu, 1994: IX). Social agents, 'depending on their personal history and therefore their dispositions', select some of the meanings offered by the institution. The institution itself offers a 'space of pre-processed possibilities. It regulates dispositions: it constraints and censors them at the same time that it opens routes to them' (Maître and Bourdieu, 1994: VI).

Maitre agrees with Bourdieu's theoretical proposition that a dialectics exists between individual and institutions, and links his own work to Bourdieu's sociology: 
In The Rules of Art, you said the field was providing social agents with a legitimate form to fulfill their wishes (désirs), and the phrase got me thinking. When one speaks of 'wish' (désir), one can be on psychoanalytical grounds, but from the moment one speaks of legitimacy, of field, one is on the sociological side. Knowing how this negociation between wishes and legitimacy works for each person is the crux of the matter. (Maître and Bourdieu, 1994: VII)

They then discuss some of the cases studied by Maître, as instances of relationships between instincts and institutions, and Bourdieu concludes again by remarking on the dialectical relation between the two. People, who have specific 'interests', 'instincts' and 'wishes linked with their family history', 'choose' some institutions because these institutions can provide them with ways of expressing or satisfying these instincts; but conversely, institutions 'choose' people, redirect and manage their instincts:

In the process through which somebody becomes a professor, for example, [the negociation between the instincts and the institutions] is a very long one; it begins in middle school: the pupil who seats in the first row, who raises his hand to speak, chooses the institution and is chosen by the institution because he chooses it. One can't tell which chooses which, if the institution chooses the individual or if it is the other way round. (Maître and Bourdieu, 1994: VIII-IX) 
This two-way street between wishes and institutions is finally defined by Bourdieu as the specific objet of a new discipline: 'socioanalysis'.

A socioanalysis which would truly go beyond the opposition between psychoanalysis and sociology should focus both on the way institutions work on wishes and on the way wishes work on institutions. (Maître and Bourdieu, 1994: XIX)

\section{'Institutions or, better, fields...'}

As far as this central theme of the dialogue is concerned, the discussion between Maître and Bourdieu (and implicitly between psychoanalysis and sociology) often uses correspondences. For example, they speak indifferently of 'social agents', 'individuals' or 'persons' (sujets), and of 'dispositions', 'instincts' or 'wishes', as if there were no distinction about the epistemological connotations of these terms. From the beginning, however, Bourdieu seems more cautious about one such correspondence, nevertheless often used in the text both by him and Maître: the one holding between the Bourdieusian notion of 'field' and the psychoanalytical use of the term 'institution'. At its first occurrence, Bourdieu speaks of 'the institution or, better, the field', and he elaborates on this more appropriate notion of field later in the discussion: 'One must not forget the elasticity of the institution; that's why I prefer to say "field", because there is always a space of possibles' (Maître and Bourdieu, 1994: X). Maître 
acknowledges that Bourdieu is 'right to criticize [his] excessive use of the term "institution" because it gives the wrong idea of monolitism' (Maître and Bourdieu, 1994: XII). Bourdieu concludes this line of discussion by reaffirming the superior value of the 'field':

The notion of "field" is useful in that it makes it possible to say that there is unity, within a field, "in" and "through" conflict. What unites people in a given field is conflict. They agree to disagree over the monopoly of something, and they are therefore bound by what divides them (...) The fields' elasticity is huge, and I think fields end up being much more pervert than apparatuses (les champs sont beaucoup plus pervers que les appareils), because they allow so much more. (Maître and Bourdieu, 1994: XII)

As it is clear in this last sentence, the criticism of the psychoanalytical use of the term 'institution' has nonetheless a conciliatory connection with the psychoanalytical characterization of the field as 'pervert'. This move, 'two steps forward, one step back', is, as we will see, a recurrent move used by Bourdieu to temper his objections against psychoanalysis, as soon as he utters them once again a rare courtesy, which Bourdieu never extended to economics, for example -: the dialogue with Maitre is indeed a pas-de-deuxiv.

\section{The 'guts to transgress'}


This 'affinity' approach, made of conciliation and correspondences between sociological and psychoanalytical terms, is given a new meaning later in the discussion. Bourdieu claims that such an affinity is an acquired right for him, because he had to overcome the 'collective positivist repression', dating back to the nineteenth century, which forbade him, as a sociologist, to acknowledge this proximity :

[In Janet's time], there was this collective repression, with a prevailing scientism. When I read again the Durkheimians - God knows they are still overwhelming, and we wish we would live up to them - it seems to me there is one thing for which we have made huge progress compared to them, and it is in reflexivity (...) The same goes with Marx, who was very good at 'psychoanalyzing' others, but not very reflexive (...). Saying [in The Weight of the World] that an interview was a spiritual exercize was hard. I have always thought that, I have always felt it. But there was this kind of positivist repression (refoulement positiviste): a questionnaire must be scientific (rigoureux), objective, neutral, there's no cathexis (investissement)... You must also have known this form of masochism, which passes for professional virtue. I had to wait to be the age I am now, and to have the social guts (culot social) that come with it, to be able to transgress like that. (Maître and Bourdieu, 1994: XIV-XVIII)

By refering to his current 'social guts', Bourdieu states that his consecrated position in the field of sociology in 1994 had allowed him to break with old 
habits, both individual and collective, regarding what was deemed scientifically proper in a field inherited from nineteenth century French sociology.

\section{A thirty years relationship, from repression to}

\section{transgression?}

The implicit history contained in Bourdieu's last quotation could be understood more precisely as follows: from an adhesion to - or an impossibility to explicitly defect from - a positivist repression, Bourdieu would have been increasingly able, through reflexive work in particular, but also self-confidence, to embrace his inner affinity with psychoanalysis and to call for a 'socioanalysis' as a way to 'trully go beyond the opposition between psychoanalysis and sociology'.

\section{From an imperialist sociology to a call for unity?}

Apart from Bourdieu's reluctance to assimilate 'fields' with 'institutions', and also a short passage to which I will return, the 'Avant Propos dialogué' could be read as bearing witness to the process of bridging the oppposition between sociology and psychoanalysis, and as constituting a decisive shift from Bourdieu's original epistemological stance on this matter. 
In Le Métier de sociologue - the building blocks of Bourdieu's epistemology written in collaboration with J.-C. Passeron and J.-C. Chamboredon - a Durkheimian stance is adopted and defended:

Durkheim's moto [one must explain the social by the social and by the social only] recalls the methodological decision not to prematurely give up the right to sociological explanation, or rather, not to adopt a principle of explanation borrowed from another science, be that biology or psychology, as long as the efficiency of purely sociological methods of explanation has not been fully tested. (Bourdieu et al., 1968: 35)

Even if it does not mean that sociology has the 'intention to explain sociologically each and every aspect of human reality' (Bourdieu et al., 1968: 35), such a Durkhemian stance is still very far from a call to go beyond the opposition between psychonalysis and sociology.

Moreover, Le Métier de Sociologue states very strongly that sociological concepts have their own meaning, and that no 'correspondence' between these and others from different disciplines (like the ones used in the dialogue with Maittre) is to be made. For example, Bourdieu suggests as 'a good method' never to speak of 'the unconscious' of social agents, but rather of what they do 'without knowing it', 'without being aware of it', 'unconsciously', etc. 'The unconscious' is in the text clearly referred to as psychoanalysis, as 'another tradition', which uses it 'with another meaning', not a sociological one. In Le Métier de sociologue, 
both Durkheim (who stated the difference between the 'unconscious' as a particular psychic agency and the existence of patterns of behaviour people are not conscious of) and Wittgenstein (who insisted on the difference between saying 'I have a toothache without knowing it' and 'I have an unconscious toothache') are summoned to suggest and to explain the difference - the opposition - between sociology and psychoanalysis as far as this is concerned. There is no analogy here between psychoanalytical and sociological terms, but a clear distinction is made between 'the unconscious as a specific psychic agency', as assumed by psychoanalysis, and the existence of patterns of conduct that people are not aware of' studied by sociology (Bourdieu et al, 1968: 152-153). Finally, even when Bourdieu quotes an idea by Bachelard of a 'psychoanalysis of the scientific mind', it is not without an immediate affirmation of the need 'to expand' it through the sociology of knowledge and an analysis of the social conditions in which sociological research is conducted (Bourdieu et al, 1968: 14), thus stating clearly sociology's prominence and independence.

Thirty years later in the discussion with Maittre, the general tone found in Bourdieu's works is very different. It is also different in the two of his major texts that we have singled out earlier, The Weight of the World and Pascalian Meditations, where he appears to be dealing more explicitly with psychoanalysis. 
First, The Weight of the World manifests a different way of relating with 'interviewees' and a different relationships between the interviewees' discourse and the scientific discourse of objectification - this is apparent in the discussion with Maître, where Bourdieu speaks of this book as a transgression regarding the 'positivist repression'. More particularly, one of the short texts written by Bourdieu within it, 'The contradictions of the inheritance' (Bourdieu, 1999: 507-513), makes many references, implicit or explicit, to psychoanalysis, for example when referring to 'transgression' , 'reality principle', 'identification' ('The son's identification to the father's wish to be continued...'), the 'real' and the 'ideal', 'ideal ego', 'substitute' ('the son or the daughter constituted as the father's substitutes' ), 'projection', 'regression', 'murder of the father' (by social mobility)... The theory of the cleavages of the habitus (see other contributions in this Special Section) is indeed rooted in this extended use of psychoanalytic terms and lines of reasoning.

Likewise, in Pascalian Meditations, the section 'Libido and illusion' deals with a classical sociological question (the relationships between primary and secondary or 'specialized' socializations) by stating that the conversion of dispositions, when an individual enters a field, has to do with 'a series of imperceptible transactions, semi-conscious compromises and psychological operations (projection, identification, transference, sublimation, etc.).' (Bourdieu, 1997: 197). Freud's analyses about 'compromise-formation' and 'organization of the libido' are explicitly referred to, in order to study a domain 
where Bourdieu could obviously have used sociological concepts - and Bourdieusian ones, for a start. Even more strikingly, sociology and psychoanalysis are put at the same level:

The original form of illusio is the investment in the domestic space, the place of a complex process of socialization of the sexual and sexualisation of the social. Sociology and psychoanalysis should unite their strengths (but to do so they would need to overcome their prejudices against each other) to analyze the genesis of investment in a field of social relations. (Bourdieu, 1997: 198-199)

The symmetry between 'the sexual and the social' seems a recurrent way for Bourdieu to talk about the relationships between sociology and psychoanalysis, a synecdoche even, since it was already the case in the Avant-Propos dialogué:

The world of mathematics, for an adolescent, is a world of purity, of gratuity, which makes it possible to free oneself from the sexual and the social; one should do a kind of social psychoanalysis of the choice of hard sciences as a way to distance oneself from existential problems, sexuality, but also everything that is linked with the social. (Maître and Bourdieu, 1994: XIV)

Going thirty years ahead, the dissymmetry that Le Métier de sociologue was striving both to manifest and to establish - with its definition of a sociological point of view as specific, or even as transcendent (exterior, and superior) - 
seems indeed to have given way to symmetry (the sexual and the social, sociology and psychoanalysis...) and correspondences (dispositions are equivalent to instincts, the field is almost an institution...).

\section{Return of the repressed}

But such a history - that of a sociologist progressively freed from his prejudices towards psychoanalysis, or rather made free to express his intellectual affinities - is not the whole story. And even the texts studied here can tell a different story if closely scrutinized.

Let us go back first to 'The contradictions of the inheritance', in La Misère du Monde. The text ends with two pages, displaying a general overtone much different from earlier formulations:

One should be careful not to see the family as the ultimate cause of the distress it seems to cause (...) Behind the story of the most "personal" difficulties and of apparently strictly subjective tensions and contradictions are often expressed the deepest structures of the social world and their contradictions. (Bourdieu, 1993: 716)

When Bourdieu explicitly defines the relationships between sociology and psychoanalysis, he does so by refusing to see them as alternatives to each other 
(one could argue that such an 'alternating' vision is that of Le Métier de Sociologue)v:

It is necessary to guard against thinking of these relationships as alternatives to each other. Sociology does not claim to substitute its mode of explanation for that of psychoanalysis. (Bourdieu, 1999: 512)

But Bourdieu does not resort to dichotomous symmetry. He states that sociology is concerned '... to construct differently certain givens that psychoanalysis also takes as its objects, and to do so by focusing on aspects of reality that psychoanalysis pushes aside as secondary or insignificant'. The specificity of sociology is also to take very seriously and to study for themselves realities that psychoanalysis 'treats as defenses that have to be breached to get to the essential element (for example, academic or professional disappointments, job conflicts, etc.).' (Bourdieu, 1999: 512). Moreover, Bourdieu does not call here for a unification of the explanations of sociology and psychoanalysis and he seems rather skeptical about the possibility of escaping 'eclectic rapprochements of pop psychoanalysis and soft sociology' when trying to built a 'socioanalysis' (Bourdieu, 1999: 512).

Here, rather than alternative, symmetrical or united disciplines, sociology and psychoanalysis appear as complementary ways of looking at - sometimes the same - things. And Bourdieu's point of view is clearly sociological. In his 
perspective, psychic processes do exist, but what is important for the sociologist is to look at what the social order does to them :

A true sociogenesis of the dispositions that constitute the habitus should be concerned with understanding how the social order collects, channels, reinforces or counteracts psychological processes depending on whether there is a homology, redundancy, and reinforcement between the two systems or, to the contrary, contradiction and tension. (Bourdieu, 1999: 512)

Then, even if 'it goes without saying that mental structures do not simply reflect social structures', Bourdieu insists on how the field influences wishes, and converts them into 'specific illusio' and socially approved forms. He thus focuses on one aspect of the dialectics between instincts and fields: the sociological direction of causality. Bourdieu hammers this point in by mentioning Freud's analysis of the family romance, in which daydreams can serve two ends: the ambitious goal and the erotic one, the latter, according to Freud, being often hidden behind the former. Bourdieu then adds : 'It is not up to me to confirm or deny Freud's affirmation. But I would like to recall the complementary affirmation that psychoanalysis overlooks: wishes manifest themselves within each field only under the specific form that the field assigns to them at a given moment in time and which is, more often than not, that of ambition.' (Bourdieu, 1993: 718). The social 'form' of ambition is therefore not a mere smokescreen, or a mask behind which the erotic would be hidden: the 
social context - the field - is what makes wishes manifest themselves in a particular way and exist at a given moment of time and in a given individual.

A small passage of the 'Avant-Propos dialogué' seems to pick up exactly where 'The contradictions of inheritance' stops. It asserts not only an influence of fields on wishes and desires, but stresses the very production of wishes by fields:

Wishes are constituted as they are expressed. [When a field] offers possibilities of expression to wishes, it gives them raisons d'être, it legitimizes them and therefore creates them (...) If you change the space of possibles and legitimate expressions of wishes, you change wishes themselves (...). And isn't this a reproach that could be made to psychoanalysis, which often stops looking when the social begins to work on wishes, by providing them with opportunity to express themselves, but also principles of structuration and raison d'être (...). [Freud] did not have a sophisticated enough vision of the social world as a space of possibles as a keyboard with which wishes can play and constitute themselves - to have a theory of the socialization of libido. (Maître and Bourdieu, 1994: XVI-XVII)

The understanding of sociology as a science which may use the same data and objects as psychoanalysis - but is to look at what psychoanalysis overlooks, pushes aside as details or smokescreens, or fails to grasp - is therefore much closer to the epistemology of Le Métier de Sociologue. The idea that the social 
'forms' given to psychic or psychological processes are indeed part of these processes, make them exist in a certain way and not only shape them, is similarly a strong sociological standpoint.

Such a standpoint suggests that the Bourdieusian approach vis-à-vis psychoanalysis is better understood as a sociologisation of psychoanalysis - an 'annexation [of psychoanalysis] through the sociological treatment of certain of its concepts' (Fourny, 2000: 103) - rather than as a complementary or integrated approach. To exemplify such a position, I will briefly go back to my own research on anorexia and show the way some of its results are in line with it.

First, such a sociologisation means that objects are to be chosen and constructed within the sociological approach itself, even when they seemingly 'belong' to another disciplinary realm. For example, my focus on 'anorexic practices', on what young girls labelled as anorexics actually do, comes from a sociological interest both in individual activity and social practices (as situated in social space), which can be opposed to the psychological or psychoanalytical tendency to overlook such practices as mere symptoms.

Second, the sociological stance detailed above entails explaining, as Durkheim's moto goes, 'the social by the social' and therefore looking at the chosen objects with our own sociological gaze. This is where I depart strongly 
from George Steinmetz's views regarding Bourdieu's position but also more generally about the relationships between sociology and psychoanalysis. For George Steinmetz (2006: 453) - who calls upon Vincent de Gaulejac Bourdieu 'did not recognize that Freudian/Lacanian theory could help him to avoid the problem of "sociologism ", that is, of reducing the process of the « incoporation » of the social into the individual to (...) logics of social power'. With the 'first' Bourdieu of the Craft of Sociology, but even also, as I have tried to show in this article, with the 'late' Bourdieu of the 1990's, I fail to see where the problem is for sociologists to be sociologists and to practice 'sociologism' - a criticism often uttered against Bourdieu by rational choice sociologists. For example, anorexic patients are well-known for their 'non compliance' to the hospital's requirements and point of view, and for their 'resistance' within the psychological or psychoanalytical sessions. This resistance is generally interpreted as psychological and is linked to mental pathology. Without endorsing this view, I tried to look at such resistance as a social will and way of acting, made possible by distinctive class resources. I showed that the specific ways in which anorexic patients resist medical power is not absent of social class dispositions and attitudes, such as self-assurance, a sense of entitlement, familiarity and connivance with the medical world, or a relation to 'speech' and discourse that comes with a high level of cultural capital (Author, 2003, 2009). Similarly, instead of trying to answer the question of gender the way it is framed by psychology (as a refusal or a denial of femininity, for example), I showed that anorexic practices are extreme forms of typical practices of women from the middle and upper classes, and that hospital work can be interpreted as an enduring work on patients destined to 're-feminize' them, which is oriented by and towards a specific definition of middle-class (and not upper-class) femininity (Author, 2003, 2007). 
More generally, I showed that the anorexic career is both made possible by the social properties of the young girls who engage in it and oriented towards the upper regions of social space and a specific definition of social excellence (Author, 2003, 2009). In Bourdieu's terms, quoted above, this comes down to showing that 'wishes manifest themselves within each field only under the specific form that the field assigns to them', or that fields 'constitute' and 'create' wishes and not only offer them possibilities of expression. In all these instances, what we see is the way the social world, as a space of possibles, 'socializes libido', even in its 'pathological' forms. To me sociology has much to gain from this kind of confrontation with 'unusual' objects, as long as, to paraphrase Spinoza, it strives to persevere in its disciplinary and epistemological being. But such studies can also benefit the general knowledge of these objects, as an 'unusual' way to look at them, which can possibly bring out new elements.

\section{Conclusion}

A sociological analysis of Bourdieu's relationships to psychoanalysis would require, most evidently, an analysis of their relative positions within the academic field, together with a sociological account of Bourdieu's trajectory, position, dispositions and stances. As much as I acknowledge that this would 
be most desirable, this paper never had such an intention. Its aim has been to address some very particular questions: (1) What could account for the discrepancy between the blatant elective affinities between socioanalysis and psychoanalysis and the very few explicit discussions of psychoanalysis by Bourdieu ? (2) How can we characterize Bourdieu's few explicit claims about the connections between these two fields of academic enquiry over the years? (3) Do they tell a specific history of connection between these two fields, from criticism to embracing, refusal to acceptance, repression to transgression? I have tried to show that even if such a repression-to-transgression interpretation has been suggested by Bourdieu himself, the fundamentals of his position spelled out in Le Métier de Sociologue remained the same.

I, for one, do not regret this consistency. The 'scientific' and 'positivist' roots of French sociology may appear as rigid constraints and a heavy tradition, but those roots are what made French sociology what it is, in its specificity and also its contribution. It could be argued that the richness of sociology could indeed be lost in a 'socioanalysis' that would blur the specificity of the sociological eye because of a too close proximity with psychoanalysis - at the risk, highlighted by Bourdieu, of combining 'pop psychology' with soft sociology. This is why the epistemological stance outlined in some passages of 'The contradictions of the inheritance' and in some parts of the 'Avant-Propos dialogué' seems more desirable. A 'sociologisation' of psychoanalysis, which is what Bourdieu sought, consists in the acknowledgement of both the specificity and the sovereignty of 
sociology. When sociology tackles realities that psychoanalysis also considers, it should, therefore: (1) choose its own objects: for example, look at aspects of realities which psychoanalysis deems unimportant or considers as mere defenses, (2) look at them with its own gaze: for example, not look for the sexual behind the social but for the social behind the sexual, decipher the social structure that lies under family past, and more generally hold that the 'social' is not a mere form, or language, or smokescreen, but that it is, within a sociological approach, the stuff that reality is made of. In contrast to the psychoanalysation of sociology that socioanalysis often involves, such a sociologisation of psychoanalysis seems beneficial to sociology, but it would also ensure a more fruitful, equal and complex pas-de-deux between sociology and psychoanalysis.

\section{Acknowledgements}

I want to thank Elizabeth Silva for having invited me to join, as a latecomer, the 'Psyche and habitus' project, and for her relentless help through different versions of this article. I am also particularly indebted to the editors and the anonymous reviewers of the article for their very detailed, challenging and generous comments. 


\section{Notes}

1 Paraphrasing Lucretius and his theory of atoms, Bourdieu used this expression ('les atomes crochus de l'habitus') to talk about the not so mysterious and socially constructed affinities between habituses.

2 Indexes were closely monitored by Bourdieu, and they can be used as indications of what he actually wanted to signal as important in his books.

3 All excerpts from the Avant-Propos dialogué are translated by me. To translate technical psychoanalytical terms, I used the Freudian glossary provided by http://www.psychanalyse.lu/articles/Glossaire.htm, consulted in April 2013.

4 Jean-François Fourny (2000: 104, 107) already depicts such 'oscillation' and 'hesitations' in Bourdieu's relation to psychoanalysis, but refers Bourdieu's 'ambiguity' to a 'potentially destabilizing conflict' and an 'uneasy relationship with psychoanalysis'. George Steinmetz describes also vividly these moments when Bourdieu 'takes back with one hand what he has given with the other', but likewise tends to describe them in psychological or even pathological terms, for example as a 'characteristic defensive move' (2006: 447), as a 'disavowal' which has an 'obsessive quality' (2006: 452), as an 'allergic relationship' (to Lacan) (2006: 459), as an 'affliction'(2013 : 128), a 'problem', a 'failure' or an 'error', 'because so many of Bourdieu's ideas are based on, or require integration with, psychoanalysis (especially the Lacanian version)' (2006: 448). By using the phrase 'pas-de-deux' I would like on the contrary to offer a more neutral 
depiction of the phenomena and even hint at its strategic and very conscious dimension - Bourdieu being well-known for his disciplinary reflexivity and the constant strategic maneuvers in his texts (quoting and not quoting, elevating, ridiculing or ignoring, expliciting alliances and oppositions or keeping them implicit...) (Encrevé, Lagrave, 2003).

${ }^{5}$ For a different interpretation of this sentence - Bourdieu failing to see that sociology and psychoanalysis 'were not alternatives, but that psychoanalysis filled some of the lacunae in his own theoretical approach' see (Steinmetz, 2006: 459-460).

\section{References}

Becker, H. (1963) Outsiders, New York: The Free Press of Glencoe.

Becker, H. (1964) Personal Change in Adult Life, Sociometry 27(1): 40-53.

Becker, H. (1998) Tricks of the Trade. How to think about your research while you're doing it, Chicago: University of Chicago Press.

Bordo, S. (1993) Unbearable weight. Feminism, Western Culture, and the Body, Berkeley: University of California Press.

Bourdieu, P. (1979), La Distinction. Critique sociale du jugement, Paris: Minuit.

Bourdieu, P. (1980), Le Sens pratique, Paris: Minuit.

Bourdieu, P. (1997), Les Méditations pascaliennes, Paris: Seuil.

Bourdieu, P. (1999), The Weight of the World: Social Suffering in Contemporary Society, translated by Priscilla Parkhurst Ferguson, Stanford: Stanford University Press. 
Bourdieu, P., Chamboredon, J.-C. and Passeron, J.-C., (1968), Le Métier de sociologue. Préalables épistémologiques, Paris: EHESS and La Haye: Mouton.

Bourdieu, P. (ed.) (1993), La Misère du monde, Paris: Seuil.

Brumberg, J. J. (1988), Fasting Girls. The History of Anorexia Nervosa, Cambridge: Harvard University Press.

Author (2003)

Author (2007)

Author (2009)

Deleuze, G. and Parnet, C. (1996), Dialogues, Paris: Flammarion.

Durkheim, E. (1938), L'Évolution pédagogique en France, Paris: PUF.

Fourny, J.-F. (2000), ‘Bourdieu's Uneasy Psychoanalysis', SubStance, 29 (3) : 103-112.

Glaser, B., and Strauss, A. (1967), The Discovery of Grounded Theory: Strategies for Qualitative Research, Chicago: Aldine Publishing Company.

Encrevé, P. and Lagrave, R.-M. (eds.) (2003) Travailler avec Bourdieu, Paris: Flammarion.

Luhrmann, T. (2000), Of Two Minds, New York: Alfred A. Knopf.

Maître, J. and Bourdieu, P. (1994), 'Avant-Propos dialogué', in Maître, J., L'Autobiographie d'un paranoïaque. L'abbé Berry (1878-1947) et le roman de Billy Introïbo, Paris: Economica: V-XXII. 
Mauger, G. and Pinto, L. (eds) (1994), Lire les sciences sociales 1989-1992, Paris: Belin.

McClelland, L. and Crisp, A. (2001), 'Anorexia and Social Class', International Journal of Eating Disorders, 29 (2): 150-156.

Muel-Dreyfus, F. (2003), 'Une écoute sociologique de la psychanalyse', in Encrevé, P. and Lagrave, R.-M. (eds.) Travailler avec Bourdieu, Paris: Flammarion: 227-235.

Rhys-Taylor, A. (2013), 'Disgust and distinction: the case of the jellied eel', The Sociological Review, 61(2): 227-246.

Steinmetz, G. (2006), 'Bourdieu's disavowal of Lacan: Psychoanalytic Theory and the Concepts of "Habitus" and "Symbolic Capital", Constellations, 13(4) : 445-464.

Steinmetz, G. (2013), 'Return of the repressed: the "traumatic kernel" of psychoanalysis in Bourdieusian theory', in Gorski, P.S. (ed.), Bourdieu and historical analysis, Durham: Duke University Press, 2013.

Turner, B. S. (1996), The Body and Society. Explorations in Social Theory, London: Sage.

Wills, W., Backett-Milburn, K., Roberts, M.-L., and Lawton, J. (2011), ‘The framing of social class distinctions through family food and eating practices', The Sociological Review, 59(4): 725-740. 
